\title{
Kastuś Kalinoŭski and the Belarusian National Idea: Research Problems
}

\author{
BY \\ ALIAKSANDR SMALIANČUK*
}

The Belarusian national idea is usually taken to mean the idea of the sovereignty of the Belarusian people and the uniqueness of their culture and mentality. The image of Kalinoǔski as the bearer of this idea acquired its final shape in the Belarusian historiography of the 1990s. The studies by Hienadź Kisialioŭ, Viačaslaŭ Šaĺkievič, Michaś Bič and Aliaksiej Kaŭka contributed most to this.

Kaŭka was sure that it was Kalinoŭski who was the first to formulate the Belarusian (Litvin) claims within the Polish national movement, including the idea of the independence of Lithuania-Belarus in a democratic union with Poland (Kaŭka 1991). Michaś Bič in 1993 claimed that thanks to Kalinoǔski and his supporters 'the political component, the idea of national independence of Lithuania-Belarus' (Bič 1993, 45) was conceived in the Belarusian movement of the nineteenth century. According to Šaĺkievič, Kalinoŭski considered the Uprising not as an end in itself, but as the only possible means at that time to achieve freedom and independence for Belarus (Šaĺkievič 1997, 33).

However, in the same years, other voices were heard. Uladzimir Kaźbiaruk considered Kalinoŭski to be 'one of the fake beacons' of Belarusian history (Kaźbiaruk 1990) and Alieh Latyšonak on the pages of Śviciaź magazine claimed Kalinoŭski had 'bestial hatred' towards orthodoxy. He also argued that the debate on the issue of whether Kalinoŭski was a self-conscious Belarusian was pointless (Latyšonak 1994, 36).

The 150th anniversary of the Uprising was the reason to continue the debate. Tossing aside the clearly ideological position of modern westernrussists and Great Russian chauvinists (e.g., Aliaksandr Hronski, Valiery Čarapica, Jakaŭ Traščanok) who deny not only Kalinoŭski's Belarusian idea, but cast doubt on the very existence of the Belarusian nation, we must recognize that many aspects of the

* Alieś Smaliančuk - Dr. hab. in History, The Institute of Slavic Studies, Polish Academy of Sciences (Warsaw). 
topic 'Kalinoŭski and the Belarusian idea' have not yet received adequate scientific attention. ${ }^{1}$

Often, the interpretation of the issue of 'Kalinoŭski and the Belarusian idea' lacked precisely a historical approach that would take into account the realities of the mid-nineteenth century. This resulted in a clear modernization of the past. Researchers treated Kalinoŭski as if he were their contemporary, or at least as a person who lived and worked in the 'age of nationalism'. Meanwhile, in the $1860 \mathrm{~s}$ there was little evidence that this age had come to the Belarusian lands.

It was often ignored that the Belarusian idea, like any other, had a long formation phase and evolved over time. For example, in the first half of the nineteenth century there was a significant process of a certain Belarusian cultural accumulation within the Lithuanian (Litvin) and Westernrussism ideological currents (Smaliančuk 2004, 51-56).

We must realize that the problem of 'Kalinoŭski and the Belarusian National Idea' is not merely a question of his world view and his own sense of national identity. Its integral component is the study of the genesis and evolution of the idea itself. It is clear that in Kalinoŭski's time the understanding of the Belarusian idea could not be the same as during the Naša Niva period.

An important element is the study of the formation and evolution of the 'Polish idea', the content of which at some point was 'Rzeczpospolita patriotism', as well as that of the 'Lithuanian idea'. The latter did not immediately receive the ethno-cultural content that we associate with it. We should also take into account the policy of the Russian authorities in the Belarusian and Lithuanian lands, and their attitude towards ethnic, cultural and religious features of the so-called NorthWestern Territory. Incidentally, this issue is one of the best explored today, thanks to the efforts of Mikhail Dolbilov, Darius Staliunas, Alieksei Miller, Paul Werth, Ted Weeks and others.

I think that Kalinoŭski should not be regarded as the creator or bearer of the Belarusian national idea, but as an important historical link in developing it. In my opinion, Kalinoŭski with his sense of the Belarusian idea is an example of a gradual evolution of the Lithuanian idea in the 'Belarusian direction'.

Such an interpretation clearly contests the view that the Belarusian idea originates from the nineteenth century Westernrussism (Zapadnorussizm) doctrine, supported by many Belarusian researchers (e.g. A. Latyšonak, V. Bulhakaŭ, I. Marza-

\footnotetext{
Apparently, this was the reason why one journalist of the Belarusian service of Radio Liberty under the influence of speeches by Alieh Latyšonak and Aliaksandr Hronski at a public discussion in Warsaw (November 2013) published a note titled Kalinoǔski as the Gravedigger of the Belarusian language [Каліноўскі як далакоп беларускай мовы] http://www.svaboda.org/content/article/25188453.html [accessed 15 March 2014].
} 
liuk). In contrast to Kalinoŭski, they consider the monarchist and Westernrussist Michail Kajalovič to be 'the first Belarusian nationalist' (for example, Bulgakov 2006, 41 etc.).

It should be noted that it was not only Belarusian-language propaganda by Jaśka, a Yeoman Farmer from near Viĺnia on the pages of Mužyckaja Praŭda (Peasant Truth) that was significant for treating Kalinoŭski as a 'Belarusian National Hero'. The works of the first historians of the Uprising and the memories of its leaders also played an important role.

The first volume of the official history of the Uprising by General Vasilii Ratch, titled About the Polish Rebellion in 1863 in the North-West of Russia, was published in 1867 in Viĺnia. The author had access to all investigation materials and to the Uprising's immediate Russian participants.

The book to a significant extent describes Kalinoŭski and his activities. V. Ratch argued that the uprising prepared by Kalinoŭski in Viĺnia at the initial stage was different from the uprising in Poland. The General highlighted two specific aspects of Kalinoŭski's position regarding Warsaw - social and national. The first included a 'peasant revolution' with the transfer of land to the peasants (Ratch 1867, 182). The second was based on the views of Alexander Herzen, and aimed to achieve independence of the historic Litva (Ratch 1867, 184). Treating Litva as an independent state supposedly laid the foundation for Kalinoŭski's conflict with the national government in Warsaw.

The first Polish researchers to study Kalinoŭski (Agaton Giller, Walery Przyborowski, and Bolesław Limanowski) were directly involved in the Uprising.

Przyborowski and Limanowski also mentioned that Kalinoŭski’s plans were quite distinctive from those of Warsaw. Limanowski described him as a supporter of the idea of 'popular uprising' and the revival of Poland as a 'people's federal state' (Limanowski 1882, 51, 213). Przyborowski mentioned similar facts, including the conflict between Kalinoŭski and the National Government. According to Przyborowski, Kalinoŭski stood for a federation of the free 'Litva' and Poland. Accordingly, he sought equality between the Committee in Viĺnia and the National Government in Warsaw. According to Przyborowski, Kalinoŭski was a supporter of social revolution, and he was convinced that peasants were the driving force in the struggle against Russian tsarism. He was planning to organise an exclusively peasant uprising or revolution (Przyborowski 1897-1902, 4-7).

The memoires of Józef Janowski, the Secretary of the National Government, and of Jakub Gieysztor, one of the leaders of the 'whites' in Lithuania and Belarus, confirm that Kalinoŭski had a specific point of view. The Secretary of the National Government, for example, argued that Kalinoŭski did not want any relations with 
the gentry and tried to rely only on the lower classes. He understood the union of historic Lithuania and Poland as a federation with complete independence from 'Litva'. Nor did he want to acknowledge the supremacy of the National Government, which provoked many conflicts. Janowski described him as a man who dreamed of the liberation of the people and called him 'a true apostle of the Belarusian people' (Janowski 1923, 426; Janowski 1925, 115).

Jakub Gieysztor portrayed his ideological enemy, the 'red' Kalinoŭski, as a person who devoted all his heart to the people, but also as a supporter of extreme revolutionary doctrines who was even ready to start a civil war:

At our first meeting he tried to convince me that participation of the nobility and landlords in the Uprising is unnecessary and even harmful. Common people are to win their freedom themselves and to claim the property from the landowners.

Gieysztor also argued that Kalinoŭski 'was thinking about the independence of Lithuania' (Pamiętniki 1913, 166-167, 221-222).

Only Giller treated Kalinoŭski as a 'Polish insurgent'. However, it was he who first published Kalinoŭski's dying statement called 'Do ludu Białoruskiego. Piśmo z pod szybienicy Konstantego Kalinowskiego' [To the Belarusian people. Letters from Beneath the Gallows, by Kastuś Kalinoŭski]. Giller, however, did not analyse this document that is very important for understanding the personality of Kalinoŭski (Giller 1867-1871).

Those were the conclusions of the first researchers and the above-mentioned memoires of the Uprising leaders that to a large extent became the basis for forming the image of Kalinoŭski as a Belarusian hero.

Problems begin when researchers start analysing the texts written by or attributed to Kalinoŭski. The texts miss references to the above-mentioned social and national aspects of Kalinoŭski's position. In particular, to read Mužyckaja Praŭda one would have doubts about the involvement of its author, Jaśka, a Yeoman Farmer from near Viĺnia, in the Belarusian idea. On its pages, the author does not mention Belarus, nor does he call for a peasant revolution. However, on the other hand he speaks about 'Lithuania' and advocates 'the fair Polish government' etc.

But before we start looking for the reasons why Belarus is not mentioned there, it is necessary to draw attention to a significant problem in source studies when analysing Kalinoŭski's personality. We should ponder the question of whether we know exactly which texts were written by Kalinoŭski.

We must admit that even today there is no comprehensive analysis of all the texts by Jaśka, a Yeoman Farmer from near Viĺnia. One can only talk about the attempts 
to perform such an analysis. In particular, Nina Barszczewska (Omeljaniuk), a linguist from Warsaw, when analysing the language of Mužyckaja Praŭda and Letters from Beneath the Gallows, drew attention to the significant linguistic differences of the seventh issue of the newspaper (Omeljaniuk 1989 (1), 101-109; Omeljaniuk 1989 (2), 201-208). We should also note that this issue in its content was similar to the Order to the Peasants of the Lithuanian and Belarusian Land, which appeared about the same time (June 1863) and contained false information about the rebels being helped by France, and on the return of Uniate churches to the Polish peasantry, etc.

Vladas Abramavichius, a Lithuanian historian of culture, argued that the third issue of Mužyckaja Praŭda was written by Walery Wróblewski (Abramavichius 1949); and a member of the Hrodna organisation Feliks Różański in his memoirs admitted his involvement (together with Kalinoŭski) in publication of the 'people's newspaper' called Mužyckaja Praŭda signed with the pen-name Jaśka, a Yeoman Farmer from near Viĺnia (Ražanski 2011, 217).

As it is known, Kalinoŭski's authorship of the Letter of Jaśka, a Yeoman Farmer from near Viĺnia to the Peasants of Polish Lands is contested. For example, well-known researcher and leader of the Belarusian movement Adam Stankievič was sure that Kalinoŭski would not appeal to the Belarusian peasants with the words 'We, who eat Polish bread, who live on the Polish land, we are Poles since the beginning of time' (Stankievič 2008, 230). Michaś Bič supported this view. His main argument was that the Letter had a National Government stamp, while Kalinoŭski usually sealed documents with the stamp of the Department of Lithuania (Bič 1997, 37-41). Hienadź Kisialioŭ, however, believed in Kalinoŭski’s authorship. According to him, the Letter might be an example of how difficult it was for the Belarusian Idea to carve its way (Kisialioŭ 2013, 408).

It is possible that the pen-name Jaśka, a Yeoman Farmer from near Viĺnia did not belong exclusively to Kalinoŭski. It could be a collective pen-name; it could also be used by other rebels, including those from Warsaw.

There is no doubt only in respect of the last texts by Kalinoŭski that he wrote in prison shortly before his death. Those are The Explanatory Note of February 28, 1864, and aforementioned Letters from Beneath the Gallows.

After the investigation was completed Kalinoŭski wrote two notes. One of them, dedicated to the 'Polish question', was not found. The other one of 28 February 1864 has not yet been thoroughly analysed, even though it was first published in

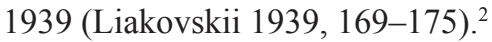

2 In 1883 A. Mosolov $(1883,1884)$ tried to retell its content and main ideas in his memories. 
In his note, Kalinoŭski confirmed that there were contradictions between the leaders of the Uprising in Poland and Litva:

The Uprising broke out in the Kingdom of Polish, it caught Lithuania completely unprepared [...] The Kingdom of Poland [...] in the uprising did not respect the interests of Lithuania (Sliedča 2014, 67).

Kalinoŭski saw the cautious attitude of the peasantry towards the leading role of the nobility and landlords as one of the reasons for the defeat:

Peasants saw the claws of their masters still not cut, they could not trust them, and began to treat the Polish undertaking as a landlords venture [...] (Sliedča 2014, 68).

The note shows that even in such a situation Kalinoŭski continued to fight. He advocated the interests of 'Lithuania' (Lithuania-Belarus) and its people and tried to influence the policy of the Russian government. Incidentally, he stressed that it was during the reign of Russia when 'the historic Litva's long developed sympathy for Poland' intensified, which determined Litva's participation in 'the Polish uprising'.

In conclusion, Kalinoŭski commented on the government's intentions to achieve a 'full merger' of 'Lithuania' with Russia

for delivering happiness to local people... I am not an opponent of happiness of the people, neither am I an enemy of Russia, if it means well to us. But I am the enemy of those disasters that strike our unfortunate region.

He warned that strengthening Russia's position in Lithuania was not possible unless the government found 'support in really educated class of the local population', etc (Sliedča 2014, 73).

Almost at the same time, Kalinoŭski was finishing his letters from beneath the Gallows that reveal Kalinoŭski's personality in a way that we are more likely to expect. There, he urged continuing the fight against the 'yoke of Moscow', because 'as long as we bear it, we won't have anything, no truth, no prosperity, no education - we will just be treated like beasts ... until we die'. The only way out Kalinoŭski saw was 'to fight for our human and national rights, for our motherland' together with 'our brothers from Warsaw' (Kastuś Kalinoŭski 1999, 46).

There arises the question of why Kalinoŭski did not voice that his position on the social and national aspects of the struggle was different from that of Warsaw.

Perhaps, to some extent, Kalinoŭski became a hostage of circumstances, because his understanding of the goals and methods of the struggle had no chance of being realized. Local peasants had not yet become the People (Nation) and 
were not aware of their social and national rights. It seems that Kalinoŭski had few adherents even among the 'red' party. Overt propaganda of a 'peasant revolution' could have led to a split among the insurgents and scared away the nobility, without which the uprising also had no chance of being successful. Incidentally, Hienadź Kisialioŭ in 1995 explained Kalinoŭski's relations with Warsaw as follows: 'To support and argue, to go as far as possible together, but to defend own interests...' (Kisialioŭ 2013, 388-389).

Texts by Jaśka, a Yeoman Farmer from near Viĺnia of 1862-1864 show rather certain evolution of the phenomenon of Litva and Rzeczpospolita patriotism towards the Belarusian idea, rather than Belarusian nationalism. Kalinoŭski began as a representative of the Litva idea, which was supported by the famous Philomaths and Filarets, Adam Mickiewicz, Adam Kirkor, Józef Kraszewski and others. The Litva idea was based on perceiving the historic Lithuania as a motherland. Litva then was free from national conflicts, and was treated as a cultural and historical entity. But at the end of the Uprising and Kalinoŭski's life, his texts more and more clearly manifested the Belarusian component of the Litva idea.

Incidentally, Hienadź Kisialioŭ saw the presence of Belarusianness even in the well-known passwords of the Viĺnia organisation: 'Whom do you love? - I love Belarus. - Me too' (Kisialioŭ 2013, 380).

Belarusianness is present in the language of Mužyckaja Praŭda and Letters from Beneath the Gallows. One should not interpret Mužyckaja Praŭda solely as a means of propaganda. The level of the Belarusian language in these texts is quite high, which indicates that the author was actively using it. Of course, an important indicator of Kalinoŭski's Belarusianness was a lyric poem dedicated to the beloved Maryja Jamant (Maryśka čarnabrova...), which in the end turned into a poetic appeal to the People to continue to fight... (Kastuś Kalinoŭski 1999, 45). In the first part of Letters from Beneath the Gallows, which was written before the arrest and was supposed to be published in the Głos z Litwy newspaper, Kalinoŭski spoke about the need for education in the Belarusian language (Kastuś Kalinoŭski 1999, 43).

It should also be noted that Jaśka, a Yeoman Farmer from near Viĺnia in Letters from Beneath the Gallows, as well as in Issue 7 of Mužyckaja Praŭda, identified himself with a 'common Belarusian', thus clearly distancing himself from Muscovites and the Poles (or the Polish Uprising). Kalinoŭski urged the continuation of the fight for freedom, and he called for the formation of an independent government for Lithuania-Belarus:

We have to be strong and to hold our ground with a sincere belief, and our government should listen to the people and rule in its favour (Da bielaruskaha 1988, 139-142). 
The Belarusian Idea is also manifested in protection of the Uniate Church. Abolished in 1839, it remained a painful wound in the hearts of Belarusians. Adam Stankievič interpreted the pro-Union Church propaganda by Kalinoŭski as the subconscious desire of his Belarusian soul to search for syntheses, in the pursuit of a strong and most appropriate soil for bridging the religious gap that ripped the Belarusian people into two hostile parts (Stankievič 1933, 30).

Kalinoŭski was a great conspirator. In the nineteenth century this created a big problem for the police and General Murav'iov; today this is a problem for researchers. A certain mystery of Kalinoŭski is a riddle in the rise of the Belarusian Idea.

\section{References}

Abramavichius, Vladas, 1949. Bibliografia bielorusskikh periodicheskikh izdanii. 1861-1944 (manuscript), the Department of Manuscripts of the Wróblewski Library of Lithuanian Academy of Sciences, F 21-2250.

Bič, Michail, 1993. 'Nacyjanaĺnaje i ahrarnaje pyeannie ŭ čas paŭstannia 1863-1864 h.', Bielaruski histaryčny časopis, 3.

—, 1997. ‘...I dumaŭ ab samastojnasci Litvy’, Bielaruskaja minuǔščyna, 5.

Bulgakov, Valierii, 2006. Istoria bielorusskogo natsionalizma. Vilnius: Institut bielorusistiki.

Da bielaruskaha liudu. Listy z-pad šybienicy Kastusia Kalinoŭskaha, 1988. Maladosć, 1.

Giller, Agaton, 1867-1871. Historia powstania narodu polskiego w 18611864 r., t. 4, Paryż: Księgarnia Luxemburgska.

Janowski, Józef, 1923. Pamiętniki o powstaniu styczniowym, t. 1, Lwów.

—, 1925. Pamiętniki o powstaniu styczniowym, t. 2, Warszawa.

Kalinovskii, Kastus', 1988. Iz piechatnogo i rukopisnogo nasliedia, Minsk: Belarus'.

Kastuś Kalinoǔski. Za našuju voĺnasć. Tvory, dakumienty, 1999. Compiled by H. Kisialioŭ, Minsk: Bielaruski knihazbor.

Kaŭka, Aliaksej, 1991. 'Bielaruski vyzvalienčy ruch', Spadčyna, 5.

Kaźbiaruk, Uladzimir, 1990. 'Majaki i viražy', Litaratura i mastactva, 7 December. 
Kisialioŭ, Hienadź, 2013. Smak bielaruščyny, Minsk: Limaryus.

Latyšonak, Alieh, 1994. 'Bielaruskaja nacyjanaĺnaja ideja', Sviciaź, 2.

Liakovskii, Alieksandr, 1939. Litva i Bielorussia v vosstanii 1863 g. (po novym arkhivnym materialam), Berlin: Arzamas.

Limanowski, Bolesław, 1882. Historia powstania narodu polskiego w $1863 i$ 1864 r., vol. 2, Lwów: Księgarnia Polska.

Mosolov, Alieksandr, 1883. 'Vilenskie ocherki', Russkaia starina, 10-12.

—, 1884. 'Vilenskie ocherki', Russkaia starina, 1.

Omeljaniuk, Nina, 1989. 'Wersje językowe gazety Mużyckaja Prauda', Studia z Filologii Rosyjskiej i Słowiańskiej, t. 15, Warszawa: Uniwersytet Warszawski.

—, 1989. 'Jeszcze o języku i autorstwie Mużyckiej Praudy i Listów z-pad szybienicy’, Studia z Filologii Rosyjskiej i Słowiańskiej, t. 18, Warszawa: Uniwersytet Warszawski.

Pamiętniki Jakóba Gieysztora z lat 1857-1865, 1913. t. 1, Wilno: nakł. Tow. Udz. Kurjer Litewski.

Przyborowski, Walery, 1897-1902. Dzieje 1863 roku, Kraków: W. L. Anczyc.

Ratch, V., 1867. Svedinia o pol'skom miatiezhe 1863 g. v Severo-Zapadnoi Rossii, vol.1, Vilnius.

Ražanski, Feliks, 2011. Z Haradzienskaha vajavodstva, Kalinoǔski i jaho epocha ŭ dakumientach i kuĺturnaj tradycyi, ed. Alieś Smaliančuk, Minsk: Bielaruskaje Histaryčnaje Tavarystva.

Šaĺkievič, Viačaslaŭ, 1997. 'Kalinoŭski Kastuś', Encyklapiedyja historyi Bielarusi, vol. 4, Minsk: BelEN.

Sliedča-sudovaja sprava Kastusia Kalinoŭskaha, 2014. Compiled by Zmicier Kuzmienka, Minsk: Halijafy.

Smaliančuk, Alieś, 2004. Pamiž krajovasciu i nacyjanaĺnaj idejaj. Poĺski ruch na bielaruskich i litoŭskich ziemliach. 1864 - liuty 1917, 2d edition with additions and amendments, St Petersburg: Neŭski Prasciah.

Stankievič, Adam, 1933. Kastuś Kalinoŭski, 'Mužyckaja praŭda' i ideja niezaliežnasci Bielarusi, Viĺnia: Vydaviectva Bielaruskaha Nacyjanaĺnaha Kamitetu.

—, 2008. Kastuś Kalinoŭski. Mužyckaja praŭda i ideja niezaliežnasci Bielarusi, Z Boham za Bielaruś. Zbor tvoraŭ, Viĺnia: Instytut bielarusistyki. 